\title{
Public Land Grazing in California: Untapped Conservation Potential for Private Lands?
}

\section{Working landscapes may be linked to public lands.}

\section{By Adriana Sulak and Lynn Huntsinger}

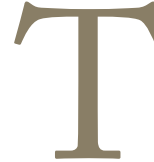

he growing interest in conservation of working landscapes and the attention paid to ranchland protection reflects a growing recognition of the environmental values of production landscapes, dissatisfaction with what sometimes appears to be gridlocked, under-funded public lands management, and decreasing public funding for fee title acquisition. Yet productive private rangelands are often linked to public land leases. In this research, we examined the relationship between the accessibility and management of these leases and ranch sustainability in 2 areas of California. Findings suggest that an overlooked tool for the conservation of working landscapes is the use of public land grazing for stabilizing livestock operations. Public land grazing could be the glue holding many ranching communities together in the face of strong pressures to convert private rangeland to more intensive uses.

\section{California: The West's Shared Future?}

There are now over 36 million people living in California, and in 2000 those 30 or so million people were living at a density of 217 people per square mile-this is orders of magnitude more densely settled than any other western state. ${ }^{1}$ Additionally, consider that California is half publicly owned overall and that $63 \%$ of California's rangelands are privately owned. ${ }^{2}$ This equals intense pressure for residential and commercial land uses, and over the past decade California has lost tens of thousands of rangeland acres per year. ${ }^{2}$ California's iconic livestock industry and bucolic rangelands are at a crossroads.

This article has been peer reviewed.

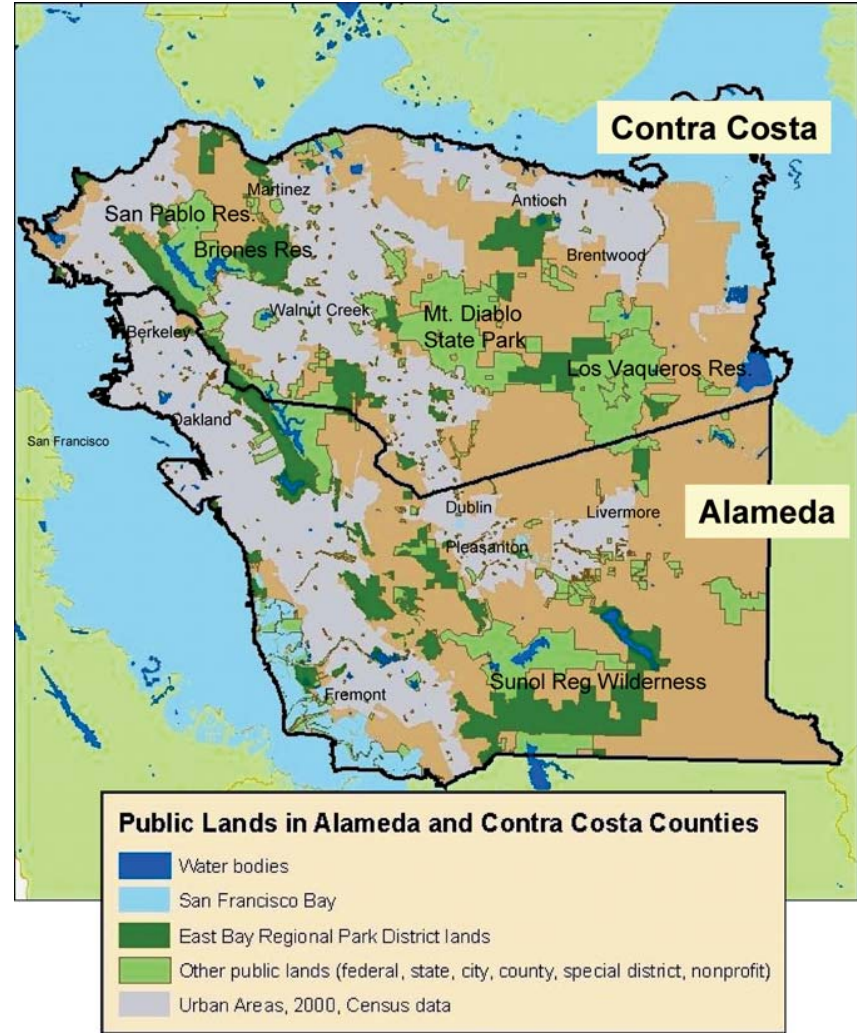

Figure 1. Case study area in the San Fransisco Bay Area.

Ranchers all across the West face serious challenges including heirship issues, increasing property taxes, worsening industry economics, losses of infrastructure, increasing conflicts with urban neighbors, fragmentation and development 


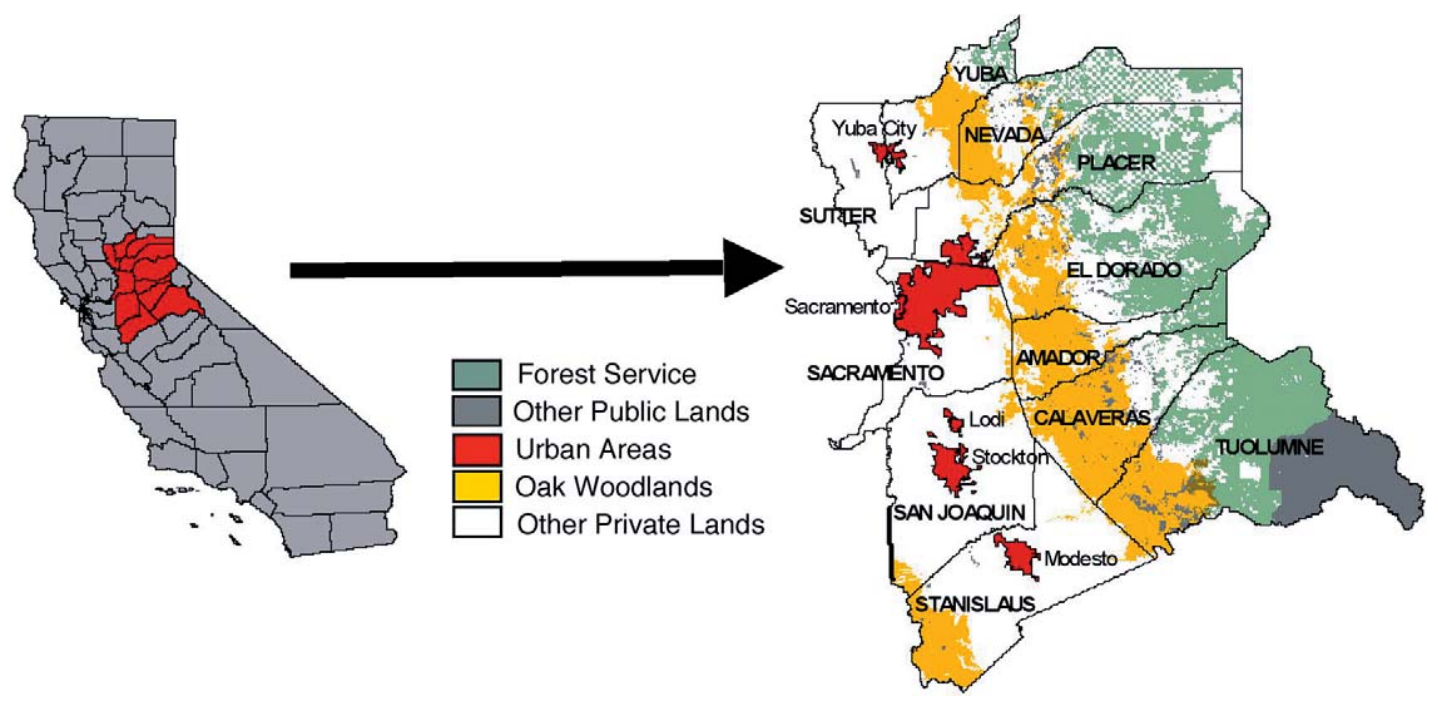

Figure 2. Case study area in the west central Sierra Nevada.

of grazing lands, and an unstable forage base. ${ }^{3-13}$ Results from this study show that the stability of public land grazing is important to the sustainability of environmentally important private western rangelands.

The use of public lands and private lands by livestock operations has been common since the first public land management agencies were established. Most Americans are aware that public land grazing occurs on federal lands but many do not realize that it is found on other types of public lands as well - city, town, utility, and local parklands. Using livestock grazing for vegetation management is accepted and defended by many government agencies, and land trusts, as an integral part of land management. It can be used for fire fuel reduction, restoring native plants, promoting biodiversity, and enhancing wildlife habitat, including habitat for special status species. $^{14-16}$

Nevertheless, despite much research documenting the benefits of grazing for conservation goals, there are widespread negative perceptions of public land grazing due to historical mismanagement, controversial politics, a shift in public lands goals to emphasizing "pristine nature," and conflicts with recreation and wildlife management. Whatever the reason, livestock grazing on public lands has declined in recent decades. ${ }^{17}$

\section{Two Different but Similar Californias}

Our research was conducted in 2 study areas within California: the San Francisco Bay Area's eastern counties and the western foothills of the Sierra Nevada mountain range (Figs. 1 and 2). Among the cities and sprawling housing developments of the San Francisco area and stretching east toward the Central Valley, there is a stalwart ranching community in Alameda and Contra Costa counties using local regional park, utility, and city open space land grazing leases. The more rural but speedily growing central Sierra foothills are home to many ranchers who have long practiced a transhumance system of grazing, using the foothills in the winter and US Forest Service (USFS) montane meadows in the summer.

Public land lessees and permittees were identified from the rosters of 3 National Forests in the central Sierra and 3 local public agencies in the East Bay-the Tahoe, Eldorado, and Stanislaus forests in the central Sierra and the East Bay Regional Park District, the East Bay Municipal Utility District, and the San Francisco Public Utility Commission in Alameda and Contra Costa counties. In 2000 and 2001, 23 USFS permittees were interviewed about their use of public lands and the importance these public lands play in their operations. This was followed in 2005 and 2006 with similar interviews of 29 Bay Area lessees.

\section{The Importance of Leasing}

The amount of land a California rancher leases to complete the annual forage requirements for a herd of cows is substantial. For these groups, leasing is important in terms of acres used, forage supplied, and income generated - all from lands that are not owned or controlled by the operator. Obviously, all the ranches in the permittee/lessee groups had a public lease, as this was a requirement of the study. But what was surprising is that all but one of the central Sierra Forest Service permittees leased other lands in addition to their federal leases, and in the Bay Area, all of the cow/calf lessee operations except 2 used private leased lands in addition to their public lease. In the Bay Area group, there were 2 operations which were entirely stocker operations, and those were completely conducted on public leases.

On average, in the Bay Area group of lessees, those with private leases used an average of 4 different private leases per operation. One rancher estimated he used between 10 and 15 private leases each year. The central Sierra group also reported using multiple leases but used fewer, on average about 2.6 per operation. To emphasize this point further, we tallied up all the acreage used by the Bay Area participants and created an 
average ranch. We found that about $80 \%$ of these operations' annual acres come from leased lands of some sort-about $30 \%$ private leased acres and 50\% public leased acres. The public leases in particular are important in terms of ranch incomes. When asked, "What percentage of your ranch income is attributable to the use of your public lease?" USFS permittees and Alameda/Contra Costa lessees reported that the public lease contributed an average of $41 \%$ and $44 \%$ to their ranch income, respectively.

\section{Reactions to Losses of Public Leases}

To take the public-private connections a step further, ranchers in both groups were asked what they would do if they no longer had access to their public lease, using a format similar to that used by Rowe and Bartlett in Colorado. ${ }^{9,10}$ If central Sierra participants lost their public leases entirely, about one-third of them said they would likely sell all or part of their ranch. The Bay Area lessees had an even more dramatic response-just over half of them said they would sell their land in response to a loss of public lease access. Considering the amount of land these groups own in their regions, loss of a public permit could cause very large changes in the local landscape. These hypothesized reactions are not specific to California-Bartlett and Rowe found similar reactions in their research in Colorado with USFS and Bureau of Land Management permittees. ${ }^{9,10}$ One central Sierra permittee put his family's dilemma eloquently into words: "Public lease versus private lease? Where is the opportunity? What are the ramifications? How will we pass on this ranching operation to the next generation? These questions will be resolved over the next ten years-without public lands as an option the answers may be harder to come by for the next generation."

\section{Role of Agency Decisions and Priorities}

One major finding from the Bay Area was that since ranchers rely heavily on public leases, agency choices about who they lease to can shape the future of the livestock community. In contrast to USFS leases, Bay Area leasing agencies change lessees more often. They are not derived from early 20th-century grazing policies, and leases do not travel with specific base properties. As a result, guidelines used by these agencies for selecting permittees vary among agencies and over time. For a while, competitive bidding was attempted, but agency managers said that they discovered this did not always result in getting the best permittees. Instead, most Bay Area agencies look for lessees who are good to work with, have a record of stability, and are near the public lands for lease. Lessees, however, were often concerned that the leasing agencies were favoring large or small, new or long-term, local or outside operators. The more than 20 lessors had diverse methods for selecting lessees, and communication with the ranching community was sporadic and varied, with some of the smaller agencies lacking range management personnel or programs.

In the Sierra foothills, many permittees were using allotments that had been in the family for generations. However, different priorities for management were having an effect on the productivity of public and private forage. On public lands, fire suppression has led to an increase in buildup of woody vegetation, reducing the available forage. Fencing of riparian areas was the most common management activity on the public forests. On private summer rangelands, clearing brush to maintain forage production was the most common activity. One can foresee a divergence in landscape appearance and characteristics over time. On public and private leased lands, interestingly, lessees bore most of the cost of activities such as fencing and range improvement.

In both places, there was intense competition for the remaining private forage. Development is gobbling up rangelands in the foothills of the Bay and Sierra, and planning often diverts housing development away for cropland and toward "low value" but beautiful grazing lands. Speculative ownerships are often grazed for tax benefits and fuel reduction, but they are eventually developed and lost. Public lands play a crucial role in providing a stable forage supply.

\section{Conclusions}

If losses of public land grazing leases can have landscapescale effects, then the reverse is true as well-public policies which promote the grazing of public land for vegetation management and conservation benefits are creating regionwide ranchland conservation benefits as well. One conservation benefit that cannot be ignored is the conservation of private rangelands linked to public lands (see Talbert et al, this issue). Public agencies could influence landscape stability and management beyond their borders by working together with lessees, and according to respondents, simple improvements in communication would go a long way. Miscommunication could be avoided by clarifying chains of command so that when lessees have a question or a problem, they know with whom to speak. Taking communication a step further and integrating lessees in management decisions could produce results on the land and foster more thorough compliance from lessees in management strategies-lessees talked of instances where they could have added to management discussions because of their extensive and day-to-day knowledge of the leases. Transparency on both sides is very important in these relationships.

For those interested in incentive-based private land conservation methods, this study also has important implications. California ranchers are clearly supporting herd sizes that are beyond the grazing capacity of their own property. This makes sense, as the number of cattle needed to support a viable operation has increased over time. A traditional conservation easement protects the productive capacity of only the private single ranch - it does not ensure that a public lease will continue to be available to allow the necessary herd size for the operation.

In the Malpai Borderlands Group conservation easement program, easement restrictions are linked to the continued availability of public land leases. ${ }^{18}$ Easements are also linked 
to other benefits for the rancher, including use of a grass bank. This model could be adapted in some ways based on this research. A nonprofit group could provide grazing on reserve lands in exchange for conservation initiatives on the private ranch, such as provision of certain types of wildlife habitat or the establishment of a conservation easement. Public agencies could link public leases to ranches with conservation easements or to those carrying out private land conservation actions.

\section{Acknowledgments}

The authors thank the ANR CORE Grants Program, the IHRMP, the California Rangeland Trust, the Sierra Nevada Alliance, the National Fish and Wildlife Foundation, and the Agricultural Experiment Station for providing funding for this project. Advisory Groups in the Sierra and in the East Bay played a crucial role in the project, and we are grateful for their time and guidance. Our advisers included Larry Forero, Sheila Barry, Laurel Ames, David Amme, Tom Bartlett, Steve Bishop, Steven Blank, Cristi Bozora Creegan, Sue Britting, Ray Budzinski, Bill Frost, Helen Howe, Tim Koopman, Sharon Johnson, Dan Macon, Michelle McFarlane, Rich Reiner, Karen Sweet, Rod Tripp, and John Woodbury. A more complete report on the Sierra Study, Sierra Nevada Grazing in Transition, is available at http://www.sierranevadaalliance. org/publications/publication.shtml?type=pgm02.

Authors are Graduate Student Researcher, University of California, Berkeley, CA 94720-3114 (Sulak); and Associate Professor, Department of Environmental Science, Policy, and Management, 137 Mulford Hall MC 3114, University of California, Berkeley, CA94720-3114, buckaroo@nature.berkeley.edu (Huntsinger).

\section{References}

1. U.S. Census Bureau. 2007. State and county quickfacts. Data derived from Population Estimates, Census of Population and Housing, Small Area Income and Poverty Estimates, State and County Housing Unit Estimates, County Business Patterns, Nonemployer Statistics, Economic Census, Survey of Business Owners, Building Permits, Consolidated Federal Funds Report. Available at: http://quickfacts.census.gov/qfd/index. html. Accessed 1 February 2007.

2. California Department of Forestri and Fire ProtecTION. 2003. The changing California: Forest and range 2003 assessment [assessment summary]. Sacramento, CA: State of California, The Resources Agency, Fire and Resource Assessment Program.

3. Anderson, M. A., S. C. Blank, T. Lamendola, and R. J. Sexton. 2002. California's cattle and beef industry at the crossroads. California Agriculture 56(5):152-156.

4. Hargreave, T. 1993. The impact of a federal grazing fee increase on land use in E1 Dorado County, California [thesis]. Berkeley, CA: University of California. 68 p.
5. Hart, J. F. 1991. Farming on the edge: Saving family farms in Marin County, California. Berkeley, CA: University of California Press. 174 p.

6. Huntsinger, L. and P. Hopkinson. 1996. Viewpoint: sustaining rangeland landscapes: a social and ecological process. Journal of Range Management 49(2):167-173.

7. Johnson, S. G. 1998. Oaks at the edge: land use change in the woodlands or the central Sierra Nevada, California [dissertation]. Berkeley, CA: University of California; $267 \mathrm{p}$.

8. Liffmann, R. H. and L. Huntsinger. 2000. To ranch or not to ranch: home on the urban range. Journal of Range Management 53:362-370.

9. Rowe, H. I., E. T. Bartlett, and L. E. Swanson, Jr. 2001. Ranching motivations in 2 Colorado counties. Journal of Range Management 54(4):314-321.

10. Rowe, H. I., M. Shinderman, and E. T. Bartlett. 2001. Change on the range. Rangelands 23(2):6-9.

11. Sulak, A., And L. Huntsinger. 2002. The importance of federal allotments to central Sierran oak woodland permittees: a first approximation. In: R. B. Standiford, D. McCreary, K. L. Purcell [tech. coords.]. Proceedings of the fifth symposium on oak woodlands: oaks in California's changing landscape. 22-25 October 2001; San Diego, CA. Gen. Tech. Rep. PSW-GTR-184. Albany, CA: Pacific Southwest Research Station, Forest Service, U.S. Department of Agriculture. $846 \mathrm{p}$.

12. Sulak, A., And L. Huntsinger. 2002b. Sierra Nevada grazing in transition: The role of Forest Service grazing in the foothill ranches of California. South Lake Tahoe, CA: Sierra Nevada Alliance, California Rangeland Trust, and California Cattlemen's Association. Available at: http://www. sierranevadaalliance.org/publications/ Sierra\%20Nevada\%20Grazing.pdf. Accessed 1 May 2007.

13. Wacker, M. J., And N. M. Kelly. 2004. Ranchers vs. ranchettes in California's oak rangelands. Rangelands 26:17-22.

14. East Bay Municipal Utility District. 2001. East Bay Watershed Range Resource Management Plan. Prepared with assistance from La Cuesta Consulting and Merritt Smith Consulting.

15. Holecheck, J. L., T. T. Baker, J. C. Boren, and D. Galt. 2006. Grazing impacts on rangeland vegetation: what we have learned. Rangelands 28(1):7-13.

16. Nuzum, R. C. 2005. Using livestock grazing as a resources management tool in California. Concord, CA: Contra Costa Water District Watershed and Lands Department. July. Available at: http://www.ccwater.com/files/ LivestockGrazingFinal72005.pdf. Accessed 1 May 2007.

17. Forero, L. 2002. Grass, grazers and tenure: A case study on the Shasta-Trinity National Forest [dissertation]. Berkeley, CA: University of California. $171 \mathrm{p}$.

18. Sayre, N. 2005. Working wilderness: The Malpai Borderlands Group and the future of the western range. Tucson, AZ: Rio Nuevo Publishers. 